\title{
Rapid Procedure for Genomic DNA Extraction from Pigeon Pea
}

\author{
Jayant Pralhad Rathod ${ }^{1 *}$, Rajendra M. Gade ${ }^{1}$ and Darasing R. Rathod ${ }^{2}$ \\ ${ }^{I}$ Vasantrao Naik College of Agricultural Biotechnology, Dr. Panjabrao Deshmukh Krishi \\ Vidyapeeth, Waghapur Road, Yavatmal-445001, Maharashtra, India \\ ${ }^{2}$ Dr. Panjabrao Deshmukh Krishi Vidyapeeth, P.O. Krishi Nagar, Akola-444104, \\ Maharashtra, India \\ *Corresponding author
}

\section{A B S T R A C T}

\begin{tabular}{|l|}
\hline Ke y w o r d s \\
DNA, Pigeon pea, \\
Extraction, Rapid, \\
Purity \\
\hline Article Info \\
\hline $\begin{array}{l}\text { Accepted: } \\
\text { 10 November } 2018 \\
\text { Available Online: } \\
\text { 10 December } 2018\end{array}$ \\
\hline
\end{tabular}

Keywords

DNA, Pigeon pea,

Extraction, Rapid,

10 December 2018

\begin{abstract}
For many crucial experiments in gene cloning and further identification, purified and high quality genomic DNA is the prerequisite. In plants, polysaccharides and secondary metabolites impurities removal is complicated and time-consuming protocols are available for pigeon pea plant. In present study, rapid and proficient method for DNA extraction was optimized. The method utilizes small amount of plant material to lessen inhibitory agents like polysaccharides and phenolic compound. The method involved crushing of the young leaf in lysis buffer, incubation at $65^{\circ} \mathrm{C}$, extraction by phenol: chloroform: isoamyl alcohol and finally DNA precipitation by cold ethanol. The results showed highly pure DNA.
\end{abstract}

\section{Introduction}

Isolation of genomic DNA from plants of high purity is very crucial experiment for isolation of specific gene of interest, identification of transformed plants and many more. For these purposes, pure and high concentration of genomic DNA is required. Different authors described different methods for DNA isolation (Tiwari et al., 2012; Agbagwa et al., 2012; Amani et al., 2011; Joshi et al., 2010; Cingilli et al., 2005). For any biotechnological application, genomic DNA extraction should be fast, simple and inexpensive by using small amount of starting material (Agbagwa et al.,
2012). For PCR, good quantity and purified genomic DNA is the first requisite either for specific gene isolation or identification of transformants (Rathod et al., 2017). Purified genomic DNA is also required for amplified fragment length polymorphism (AFLP), sequence-related amplified polymorphism (SRAP), simple sequence repeats (SSR) and random amplified polymorphic DNA (RAPD) (Agbagwa et al., 2012).

Also the genomic DNA extraction from plant is difficult because of presence of a rigid cell wall with different composition surrounding the plant cells and it varies between species 
(Joshi et al, 2010). The most commonly used DNA extraction procedure for plants is cetyl trimethyl ammonium bromide (CTAB) method (Doyle, 1990).

We report here a rapid and simple method without using $\mathrm{CTAB}$ and $\beta$-mercaptoethanol. Liquid nitrogen was used to lower the temperature at crucial step and to reduce the overnight time required earlier by Joshi et al., 2010 to $2-5$ mins. The method utilizes $1.5 \mathrm{ml}$ of eppendorf/microcentrifuge tube during the entire process as opposed to higher volume tubes. The mixing is also performed manually to reduce the time. The effectiveness of our method was validated using Spectrophotometer quantification and purity at 260/280 ratio. The DNA yield and purity was so high that the DNA can be directly further used for AFLP, RAPD, SSR, etc., analysis along with isolation of gene.

\section{Materials and Methods}

Three different varieties of pigeon pea (Cajanus cajan) Maruti, Asha and AKPR were procured from Krishi Vigyan Kendra, Yavatmal, Maharashtra and grown in pots at Vasantrao Naik College of Agricutural Biotechnology, Yavatmal, Maharashtra. The fresh young leaves grown on the plantlets of these three varieties were used for DNA extraction. $100 \mathrm{mg}$ of young leaf tissue separately from different pigeon pea varieties were transferred to separate pre-chilled mortar and pestle and crush with $1 \mathrm{ml}$ of lysis buffer (250 mM NaCl, $25 \mathrm{mM}$ EDTA (pH 8.2), 0.5\% SDS, $200 \mathrm{mM}$ Tris base, polyvinylpyrrolidone (PVP) $0.1 \mathrm{~g}$ for $1000 \mathrm{ml}$ extraction buffer solution) in separate mortar pestle. After crushing, the extracts were transferred to different autoclaved microcentrifuge tube. All the tubes were processed in similar manner as mentioned below. The microcentrifuge tubes with ground homogenate were incubated at $65^{\circ} \mathrm{C}$ for 30 min using float. The tubes were centrifuged at $14000 \mathrm{rpm}$ for $2 \mathrm{~min}$ at $4^{\circ} \mathrm{C}$ using cooling centrifuge (Eppendorf, Germany). The supernatant was collected in fresh labelled tubes with the help of micro pipette and added equal volume of chloroform: isoamyl alcohol (24:1) to the samples. The tubes were gently mix by inverting it slowly 15-20 times to ensure maximum extraction of pigments in the chloroform layer. The tubes were centrifuge at $14000 \mathrm{rpm}$ for $10 \mathrm{~min}$ at $4^{\circ} \mathrm{C}$. The supernatant were carefully transferred to new tubes with micro pipette and $12 \mu \mathrm{l}$ of RNase $(1 \mathrm{mg} / \mathrm{ml}$ stock) was added to each supernatant separately and mixed gently by inverting the tubes 5-10 times. The tubes were incubated at $37^{\circ} \mathrm{C}$ for $30 \mathrm{~min}$ in water bath. Equal volume of phenol:chloroform:isoamyl alcohol (25:24:1) was added to the samples and mix gently by inverting the tubes 4-6 times and centrifuged at $14000 \mathrm{rpm}$ for $5 \mathrm{~min}$ at $4^{\circ} \mathrm{C}$. The aqueous layer was transferred to a new tube and re-extract with equal volumes of chloroform and isoamyl alcohol (24:1) by centrifuging at $14000 \mathrm{rpm}$ for $5 \mathrm{~min}$ at $4^{\circ} \mathrm{C}$. The aqueous layer was collected in fresh microcentrifuge tube and equal amount of chilled ethanol (100\%) was added to it and kept it in liquid nitrogen in cryo box (Tarson) for 2-4 mins till the liquid got solidified. The microcentrifuge tubes were thawed on ice and the tubes were centrifuge at $14000 \mathrm{rpm}$ for 5 min at $4{ }^{\circ} \mathrm{C}$. The supernatant was discarded and $500-750 \mu \mathrm{l}$ of chilled $70 \%$ ethanol was added to the pellet of each tube and the tubes were inverted gently 4-6 times to wash the DNA pellet. The tubes were again centrifuged at $14000 \mathrm{rpm}$ for $5 \mathrm{~min}$ at $4^{\circ} \mathrm{C}$ and the supernatant was discarded using micro pipette. The tubes were transferred to Vacuum evaporator (Eppendorf, Germany) and vacuum evaporated the ethanol for 2-5 mins depending on the amount of ethanol present in the microcentrifuge tube. $100 \mu \mathrm{l}$ TE extraction buffer $(10 \mathrm{mM}$ Tris base and $1 \mathrm{mM}$ EDTA, $\mathrm{pH}$ 8.4) was added to dissolve the DNA and 
the yield and purity of DNA was measured using UV-visible spectrophotometer (Eppendorf, Germany) at 260 and $280 \mathrm{~nm}$.

\section{Results and Discussion}

The yield and purity of genomic DNA was noted as shown in Table 1 of three different varieties in triplicate.

The concentration and purity of the DNA isolated from $100 \mathrm{mg}$ sample was found to be very high and it can be use for different PCR based analysis such as amplified fragment length polymorphism (AFLP), random amplified polymorphic DNA (RAPD), simple sequence repeats (SSR), etc., to identify the similarity and differences among these pigeon pea varieties. This method is modified method as earlier described by Joshi et al., 2010 for Chickpea. The rapid method was designed by keeping in mind time required by Bachelors students in their practical time in approximately 100 min by keeping in mind $120 \mathrm{~min}$ of their practical time. Also this method is useful for screening large number of pigeon pea transformants.

The problems with DNA isolation is protein, RNA and polysaccharide impurities which interferes with crucial cloning steps (Amani et al., 2011). Present protocol resulted in extraction of high quality DNA from three different varieties of pigeon pea. The polysaccharide impurities can be removed by using young leaves which we tried and got best results which was evident from 260/280 ratio between 1.8 and 2 . $\beta$-mercaptoethanol is usually used to improve DNA quality (Paterson et al., 1993). In our protocol $\beta$ mercaptoethanol was not used and quality of DNA was also not got affected. Also Tris$\mathrm{HCl}$ was replaced by Tris Base without affecting the DNA quality and that is the novelty of our protocol along with reduction of time for isolation of genomic DNA. CTAB is usually used for removal of polyphenolics and/or polysaccharides (Doyle, 1990). In our method CTAB was not used without affecting DNA quality which was another novelty. Also removal of RNA from DNA isolated sample is major issue for some PCR reactions because RNA can hamper by suppressing it in PCR amplification patterns in RAPD analysis (Pikart and Villeponteau, 1993). We have got purified DNA with no RNA impurity thus this method can be used for RAPD and other PCR analysis.

Table.1 Concentration and purity of genomic DNA isolated from different varieties of Pigeon pea

\begin{tabular}{|c|c|c|}
\hline Pigeon pea variety & $\begin{array}{c}\text { Concentration of DNA } \\
\left(\text { ng. } \mu 1^{-1}\right)\end{array}$ & Purity(260/280 ratio) \\
\hline Maruti 1 & 550.12 & 1.86 \\
\hline Maruti 2 & 559.97 & 1.89 \\
\hline Maruti 3 & 561.11 & 1.90 \\
\hline Asha 1 & 225.13 & 1.79 \\
\hline Asha 2 & 231.24 & 1.83 \\
\hline Asha 3 & 220.59 & 1.77 \\
\hline AKPR 1 & 913.61 & 1.84 \\
\hline AKPR 2 & 893.26 & 1.89 \\
\hline AKPR 3 & 897.31 & 1.82 \\
\hline
\end{tabular}




\section{References}

Agbagwa, I. O., Datta, S., Patil, P. G., Singh, P., and Nadarajan, N. 2012. A protocol for high-quality genomic DNA extraction from legumes. Genet $\mathrm{Mol}$ Res, 11(4), 4632-4639.

Amani, J., KAZEMI, R., Abbasi, A. R., and Salmanian, A. H. 2011. A simple and rapid leaf genomic DNA extraction method for polymerase chain reaction analysis.

Cingilli, H., and AKÇİN, A. 2005. High quality DNA isolation method for chickpea genotypes. Turkish Journal of Biology, 29(1), 1-5.

Doyle, J. J. 1990. Isolation of plant DNA from fresh tissue. Focus, 12, 13-15.

Joshi, N., Rawat, A., Subramanian, R. B., and Rao, K. S. 2010. A method for small scale genomic DNA isolation from chickpea (Cicer arietinum L.) suitable for molecular marker analysis. Indian Journal of Science and Technology,
3(12), 1214-1217.

Paterson, A. H., Brubaker, C. L., and Wendel, J. F. 1993. A rapid method for extraction of cotton (Gossypium spp.) genomic DNA suitable for RFLP or PCR analysis. Plant Molecular Biology Reporter, 11(2), 122-127.

Pikaart, M. J., and Villeponteau, B. 1993. Suppression of PCR amplification by high levels of RNA. Biotechniques, 14(1), 24-25.

Rathod, J. P., Gade, R. M., Rathod, D. R., and Dudhare, M. 2017. A Review on Genetic Engineering of Microalgae with Respect to Genomes, Selectable Marker Genes, Promoters and Reporter Genes. Int. J. Curr. Microbiol. App. Sci, 6(12), 3208-3219.

Tiwari KL, Jadhav SK and Gupta S. 2012. Modified CTAB Technique for isolation of DNA from some medicinal plants. Res. J. Med. Plant 6: 65-73.

\section{How to cite this article:}

Jayant Pralhad Rathod, Rajendra M. Gade and Darasing R. Rathod. 2018. Rapid Procedure for Genomic DNA Extraction from Pigeon Pea. Int.J.Curr.Microbiol.App.Sci. 7(12): 863-866. doi: https://doi.org/10.20546/ijcmas.2018.712.107 